\title{
Banner waste mixture: The impact on quality of traditional brick's compressive strength
}

\author{
Okky Fajar Tri Maryana ${ }^{*}$, Rifqi Ikhwanuddin ${ }^{2}$, Safitri Anggini $^{3}$, Ridho Barna ${ }^{4}$ \\ 1,3,4 Physics Department, Institut Teknologi Sumatera, Lampung, Indonesia \\ ${ }^{2}$ Engineering Physics Department, Institut Teknologi Sumatera, Lampung, Indonesia.
}

*Corresponding Address: okky.trimaryana@fi.itera.ac.id

\begin{tabular}{|c|c|}
\hline Article Info & ABSTRACT \\
\hline Article history: & The regional election in Lampung province has finished. The events left the \\
\hline $\begin{array}{l}\text { Received: December } 9^{\text {th }}, 2019 \\
\text { Accepted: June } 9^{\text {th }}, 2020 \\
\text { Published: October } 29^{\text {th }}, 2020\end{array}$ & $\begin{array}{l}\text { amount of ex-campaign props such as banner to become waste. The final } \\
\text { landfills and the waste reuse system are still an unsolved issue in Lampung } \\
\text { province. A study of materials composition is required to find potential } \\
\text { reuse of the waste. One of the traditional products in Lampung province is }\end{array}$ \\
\hline & $\begin{array}{l}\text { conventional bricks. Previous studies show that mixing local clay with } \\
\text { additional materials such as Rice Husk Ash (RHA) could improve its }\end{array}$ \\
\hline $\begin{array}{l}\text { Banner; } \\
\text { Banner waste mixture; } \\
\text { Brick; } \\
\text { RHA. }\end{array}$ & $\begin{array}{l}\text { characteristics, especially water absorption potentiality. This study reported } \\
\text { the prototype of bricks with banners waste mix produced employing a } \\
\text { conventional method. The method obtains the best admixture composition is } \\
0.002 \text { kilograms banner waste/volume } 0.125 \text { liters or } 0.02 \% \text { total weight of } \\
\text { clay-dough. The morphology of the prototype shows a similar texture with a } \\
\text { non-waste mixture of traditional brick. It is burnt-clay red-bricks, which is } \\
\text { used as a control in this study. The prototype bricks show smooth texture } \\
\text { and nearly flat on all sides. The addition waste composition ratio of more } \\
\text { than } 0.002 \text { kilograms indicated cracking texture that affects the market tend } \\
\text { to buy bricks, which has good appearance and texture. This study also } \\
\text { reported that the mixture's effect is decreasing compressive strength, almost } \\
20 \% \text { from the control sample. }\end{array}$ \\
\hline
\end{tabular}

(c) 2020 Physics Education Department, UIN Raden Intan Lampung, Indonesia.

\section{INTRODUCTION}

Environment-friendly building materials receive significant attention from scientists and engineers (Ahmed et al., 2018; Al-Fakih et al., 2019; Rajkumar et al., 2016). Motivation in the use of environmentally friendly building materials is based on environmental regulations, impacts on the environment and human health, the goal of global decarbonization, and the use of recycled materials (Babu \& Krishnaiah, 2018; Murmu \& Patel, 2018).

The bricks were made from burnt clay has been known as one of the oldest and most ecological building materials as it is created of natural raw materials (Dang et al., 2018; Hadi \& Abdelhadi, 2018; Soultana et al., 2019). Several studies have shown that mechanical properties as a compression test of red bricks can be mixed with other waste materials to obtain higher or lower compressive strength (Kizinievi et al., 2018; Murmu \& Patel, 2018; Velasco et al., 2014)

Printed media made of vinyl-banner is favorably used in Indonesia. Consequently, vinyl-banners based materials are massively found unused straight after the regional election period. Other than vinyl-banner materials, several studies (Silva \& Perera, 2018; Velasco et al., 2014) have been conducted to investigate the possibilities of recycling waste materials into a new product as a sustainable building material. 
Rice Husk Ash (RHA) addition in burnt clay bricks' manufacturing process has been studied at least by Rahman and Silva (Rahman, 2014; Silva \& Perera, 2018). The RHA addition shows potential since it improves mechanical properties while lowering the water absorption case (Rahman, 2014). In recent studies (Kizinievi et al., 2018), brick dough in a conventional technique is developed with other waste materials to promote waste products' lifecycle. This study compared various waste into the bricks as new eco-building material (Ahmed et al., 2018).

In the research context of waste recycling, the present study focuses on using printed media vinyl-banner waste in clay brick compounds for civil construction as a house structure. However, the physical test taking place is limited to only visual appearance, product dimension, and the compression test. Although the bricks industry is highly promising for green building structure (Abbas et al., 2017; Babu \& Krishnaiah, 2018; Balaji et al., 2018), little information is known about the study reuse of printed media vinyl-banner waste in based clay materials. Recycling such waste by incorporating them into building materials is a practical solution to the pollution problem (Kadir \& Sarani, 2012; Zhang, 2013).

This study's main objective is to investigate and reported the study effects of printed media vinyl-banner waste as additives materials on the physical properties of conventional bricks products in Yosomulyo district Lampung Province.

\section{Materials Brick}

Brick is made from clay. Clay's properties are soft, loose, earthy material containing particles with a grain size of fewer than 4 micrometers $(\mu \mathrm{m})$ (Ahmad et al., 2017). Generally, It forms as a result of the weathering and erosion of rocks containing the mineral group feldspar over extended periods (Joglekar et al., 2017; Rani et al., 2016). A brick dough can be molded to become clay brick. Clay soil also easily can be found in the farming area (Kizinievi et al., 2018; Muntohar, 2011). It has unique characteristics such as plastically soft and weak in the wet condition, hardened on the dry state, and condensed solid after burnt in high temperature (Dhandhukia et al., 2013).

\section{Design and Standard}

Standardization is needed in the building materials industry to ensure the quality of its products (Letelier et al., 2018; Seco et al., 2018). Essential aspects that must be present in bricks such as morphology, dimensions, and compressive strength are generally required to be realized. According to SNI (Standard Nasional Indonesia) 15-20942000, SII-0021-78 issued by National Standard Institution on brick standard, it is recommended to follow the national guideline, see

Table 1 as follows.

Table 1. Brick dimension based on Indonesian national standard SNI 15-2094-2000, SII-0021-78

\begin{tabular}{lccc}
\hline \multirow{2}{*}{ Module } & \multicolumn{3}{c}{ Dimension $(\mathrm{cm})$} \\
\cline { 2 - 4 } & Breadth & Width & Length \\
\hline $\mathrm{M}-5 \mathrm{a}$ & 6.5 & 9 & 19 \\
$\mathrm{M}-5 \mathrm{~b}$ & 6.5 & 14 & 19 \\
$\mathrm{M}-6$ & 5.5 & 11 & 23 \\
\hline
\end{tabular}

Size deviations that are regulated according to SNI (Standard Nasional Indonesia) are shown in Table 2.

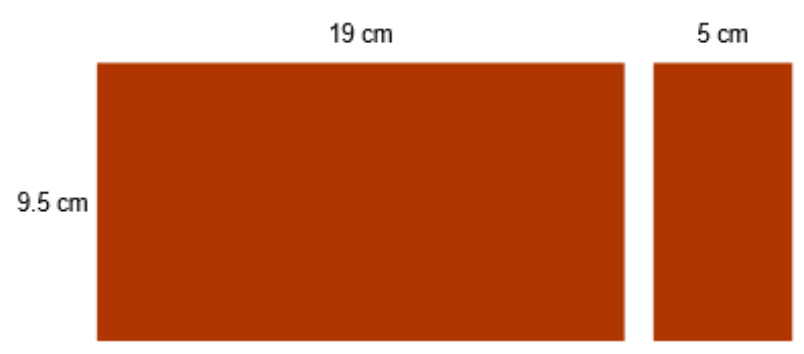

Figure 1. Clay brick prototype dimension

The compressive strength of the prototype has been tested in this study. The national standard of compressive strength 
class also addresses the properties shown in table 3 .

Table 2. Allowed brick dimension deviation SNI 152094-2000, SII-0021-78

\begin{tabular}{ccccccc}
\hline \multirow{2}{*}{ Class } & \multicolumn{4}{c}{ Maximum Deviation (cm) } \\
\cline { 2 - 7 } & \multicolumn{3}{c}{$\mathbf{M}-\mathbf{5 a}$ \& $\mathbf{M}-\mathbf{5 b}$} & \multicolumn{3}{c}{ M - 6 } \\
\cline { 2 - 7 } & $\mathbf{B}$ & $\mathbf{W}$ & $\mathbf{L}$ & $\mathbf{B}$ & $\mathbf{W}$ & $\mathbf{L}$ \\
\hline 25 & 0.2 & 0.3 & 0.5 & 0.2 & 0.3 & 0.5 \\
50 & 0.2 & 0.3 & 0.5 & 0.2 & 0.3 & 0.5 \\
100 & 0.2 & 0.3 & 0.4 & 0.2 & 0.3 & 0.4 \\
150 & 0.2 & 0.2 & 0.4 & 0.2 & 0.2 & 0.4 \\
200 & 0.2 & 0.2 & 0.4 & 0.2 & 0.2 & 0.4 \\
250 & 0.2 & 0.2 & 0.4 & 0.2 & 0.2 & 0.4 \\
\hline
\end{tabular}

$\mathrm{B}=$ Breadth, $\mathrm{W}=$ Width, $\mathrm{L}=$ Length

Even though BSN (Badan Standard Nasional) or National Standard Institution in Indonesia has established burnt clay brick a standard as mentioned above. This study design employs local best practices in the Yosomulyo district. Each brick workshop has custom and tradition inherited generation by generation. The prototype brick dimension bit different from the traditional standard.

Table 3. National standard of compressive strength class regular burnt clay-bricks SNI 15-20942000, SII-0021-78

\begin{tabular}{cccc}
\hline Class & $\begin{array}{l}\text { Minimum } \\
\text { Compressive Strength }\end{array}$ & $\begin{array}{c}\text { Coefficient of } \\
\text { Minimum } \\
\text { Compressive } \\
\text { Strength }\end{array}$ \\
\hline & $\mathbf{K g} / \mathbf{c m}^{2}$ & $\mathbf{N} / \mathbf{m m}^{\mathbf{2}}$ & $\%$ \\
\hline 25 & 25 & 2.5 & 25 \\
50 & 50 & 5 & 22 \\
100 & 100 & 10 & 22 \\
150 & 150 & 150 & 15 \\
200 & 200 & 20 & 15 \\
250 & 250 & 25 & 15 \\
\hline
\end{tabular}

The mold container of clay dough and the conventional process could be seen in Figure 2. This traditional machine needs a minimum of 10 kilograms of clay supply to fulfill its container for normally running. It can produce as many as eight pieces of wet bricks in one cycle.

Figure 1 shows the prototype dimension is closed to the $\mathrm{M}-5 \mathrm{a}$ module in
Table 1, only with a smaller standard breadth.

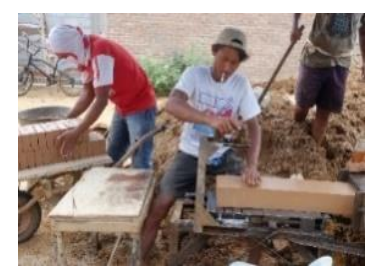

Figure 2. A conventional molding Machine produces the bricks.

\section{METHODS}

This study's prototype employs a composition of 10 kilograms of local rawclay, 0.002 and 0.004 kilograms of vinylbanner waste/volume 0.125 liters, amount 2 liters of water, and 0.01 kilograms of RHA. The conventional molding machine, plastic bag, and scissors are the main pieces of equipment for mixing the clay dough. The prototype bricks are divided into two groups of treatment, with or without vinyl-banner waste as an additive material. There are two kinds of vinyl-banner waste addition: 0.002 kilograms (in estimation $0.02 \%$ per total of dough weight) and 0.004 kilograms/0.04\%.

Ten kilograms of clay soil is prepared with 2 liters of water and 0.01 kilograms of RHA. The specific composition with 0.002 kilograms (or $0.02 \%$ per total of clay mass dough) vinyl-banner waste composition was added. Each composition was thoroughly mixed, then labeled and bagged with a huge plastic. All bags are left out for three to four days to achieve wet uniformity.

All shaped prototype clay bricks are sundried for about a week (see figure 3.) and then burnt in a kiln (together with All regular others brick product) using rice husk for three to five days.

The technique employs slow-burning (3 5 days) with $80-200^{\circ} \mathrm{C}$ of estimate average temperature to ensure heat uniformity in the pile, see Figure 3. It is analogous to heat distribution in a room with a convection pipe reported by Abdurrahman (Abdurrahman et al., 2019). Sun-dried clay 
bricks are stacked, and some sections will remain deliberately unfilled. The gaps between them are supplied with a lot of rice husk. Every day a worker will check the kiln and put on more rice husk if the gap shows up.
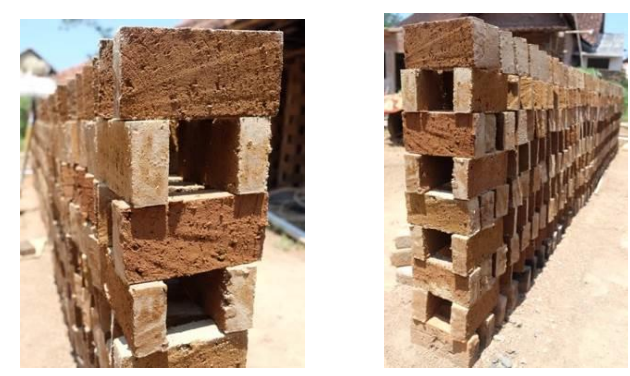

Figure 3. A pile of sun-dried clay bricks.
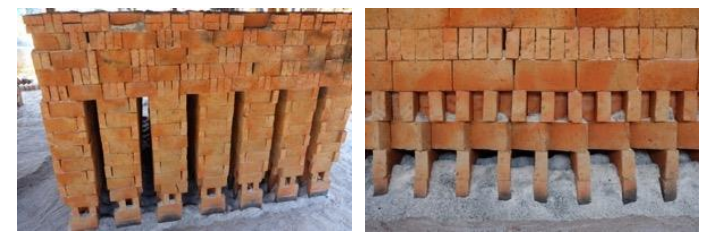

Figure 4. End-phase of the burning process with rice husk in a workshop.

\section{Compression Test}

The Compression test is employed to get the maximum compressive load that can be accepted by the prototype. Data adjustment is required with the Indonesian National Standard (SNI) of the prototype shown in table 3. Testing of the compressive strength $(\sigma)$ fit with the following equation:

$$
\sigma=F / A
$$

$\mathrm{F}$ is the crushed load $(\mathrm{kg})$, and $\mathrm{A}$ is the compressive area $(\mathrm{cm} 2)$. The SI unit of pressure $\mathrm{Kg} / \mathrm{cm}^{2}$ or $\mathrm{N} / \mathrm{mm}^{2}$.

CTM (compress test machine) was employed to get the value of prototype compressive strength (CS). CS is a parameter that indicates the amount of load per unit area that causes the test specimen (bricks prototype) to be destroyed by specific compressive forces (Ahmad et al., 2017; Amin et al., 2017; Phonphuak et al. 2016)

\section{RESULTS AND DISCUSSION}

Figure 5 shows the morphology of the prototypes brick. It is succeeded through the burning process, as evidenced by the absence of significant cracks for 0.002 kilograms vinyl-banner waste addition.

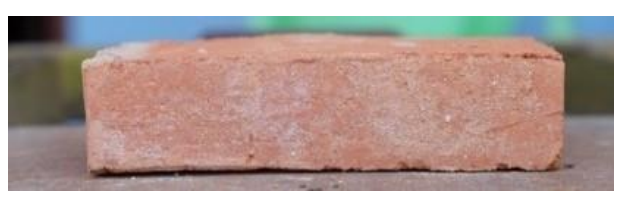

(a)

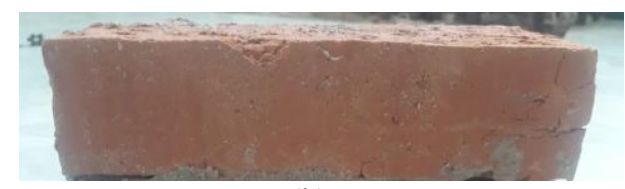

(b)

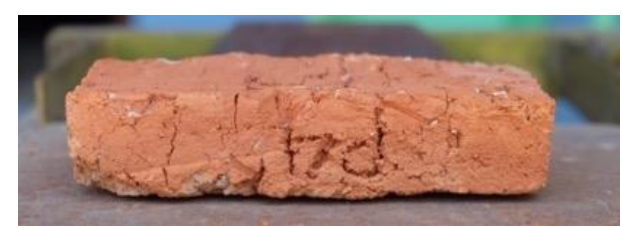

(c)

Figure 5. Three kinds of burnt-clay bricks product with a composition of 10 kilograms rawclay (a) with only 0.01 kilograms of RHA addition/ control sample, (b) RHA and 0.002 kilograms vinyl-banner waste addition, (c) RHA and 0.004 kilograms vinyl-banner waste addition.

Each type has been made several units that enough to achieve minimum quantity for test purposes. Even though clay bricks solidify and have some red brick color as they usually do, they do not have the same visual or shape appearance precisely.

The bricks were tested using compression test instrumentation. The results of compressive strength tests can be seen in table 4. Sample S.1 is rice husk ash brick with no vinyl-banner waste mixture at all. In contrast, the S.2 sample is brick, mixed with 0.002 kilograms of vinyl-banner waste. Compressive tests were carried out three times for each sample. The 0.004 kilograms (Code S.3) mixture was not tested because of the failure texture factors. We found more 
pores and lacked uniformity in most S.3 shapes (see figure 5 (c).

Table 4. Compressive strength score of the prototype

\begin{tabular}{ccc}
\hline $\begin{array}{c}\text { Code of } \\
\text { prototype }\end{array}$ & $\begin{array}{l}\text { Weight } \\
\text { (gr) }\end{array}$ & $\begin{array}{l}\text { Compressive } \\
\text { Strength } \\
\left(\mathbf{k g} / \mathbf{c m}^{2}\right)\end{array}$ \\
\hline S.1.1 & 4130 & 32,72 \\
S.1.2 & 4280 & 33,46 \\
S.1.3 & 4140 & 29,41 \\
Average & & $\mathbf{3 1 , 8 6}$ \\
S.2.1 & 3985 & 29,63 \\
S.2.2 & 3970 & 21,92 \\
S.2.3 & 4200 & 24,99 \\
Average & & $\mathbf{2 5 , 5 1}$ \\
S.3.1 & - & - \\
S.3.2 & - & - \\
S.3.2 & - & - \\
\hline
\end{tabular}

The Bricks with only 0.01 kilograms RHA showed compressive strength characteristics of $31.86 \mathrm{~kg} / \mathrm{cm}^{2}$; it showed fulfilled SNI categories above the class of 25 (table 3 ). The prototype mixture with 0.01 kilograms RHA and 0.002 kilograms of vinyl-banner waste showed compressive strength to $25.51 \mathrm{~kg} / \mathrm{cm}^{2}$, almost to $20 \%$ lost. Decreasing the compressive strength is caused by decreasing weight. The investigation shows that a mixture of vinylbanner waste increasing the pores of burntbrick. Vinyl-banner waste as additive materials in clay-dough is not melting perfectly when the burning process occurs. The more vinyl-banner waste was added, the more pores have formed. It follows with the Raut et al. result using paper mill waste as an additive material (Raut et al., 2012).

Despite the S.2 sample's compressive strength decreasing, it is still included in the SNI class of a minimum of 25 (See table 3 ). We can say that the prototype is still could be used as a building material in general production.

This study also supports previous work (Minhaj et al., 2018; Poinot et al., 2018; Taha et al., 2018). It was reported that lighter weight bricks could be produced using a mixture of the wastes, which help reduce the prototype's weight.

Most of the research carried out, including the author's study, on the production of bricks with a mixture of waste materials, continues to increase the compressive strength of bricks (Monteiro \& Vieira, 2014; Murmu \& Patel, 2018).

\section{CONCLUSION}

It can be concluded that it is possible to incorporate vinyl-banner waste into burntclay bricks fabrication. However, temporarily, their appearance is not broadly as well as regular conventional bricks. The texture lacks uniformity.

By adding vinyl-banner waste into clay dough, at last, it helps decrease the weight and or the density AND $\mathrm{C}$-the result support for producing lightweight composite building materials.

The research carried out successfully modified the bricks produced in Yosomulyo district Lampung Province. The only mixture of RHA showed an average compressive strength of $31.86 \mathrm{~kg} / \mathrm{cm}^{2}$. The addition of vinyl-banner waste of 0.002 kilograms ratio indicates a decrease to $20 \%$ score in compressive strength, and the weight of each prototype bricks made almost $2 \%$ compared with control bricks. Further study should concern report the burning temperature factor to obtain the optimum value in burning vinyl-banner waste-mixed clay.

\section{ACKNOWLEDGMENTS}

This research is part of the project funded by Kemenristek Dikti Research Grant 2019 (Grant No. B/175/IT9.C1/PT.01.03/2019).

\section{AUTHOR CONTRIBUTIONS}

OFTM conceptualized and wrote the manuscript. SA and RB collected and analysed data. RI reviewing literature and wrote the manuscript. SA arrange the research result and documentin the research process. 


\section{REFERENCES}

Abbas, S., Saleem, M. A., Syed, M. S., \& Munir, M. J. (2017). Production of sustainable clay bricks using waste fly ash: Mechanical and durability properties. Journal of Building Engineering.

https://doi.org/10.1016/j.jobe.2017.09.0 08

Abdurrahman, A., Umam, R., Irzaman, I., Palupi, E. K., Syazali, M., Junaidi, R., Wahyudianto, B., Adi, L. C., \& others. (2019). Optimization and interpretation of heat distribution in sterilization room using convection pipe. Indonesian Journal of Science \& Technology, 4(2), 204-219.

Ahmad, S., Iqbal, Y., \& Muhammad, R. (2017). Effects of coal and wheat husk additives on the physical, thermal and mechanical properties of clay bricks. Boletín de La Sociedad Española de Cerámica y Vidrio, 56(3), 131-138. https://doi.org/10.1016/j.bsecv.2017.02 .001

Ahmed, S. A., Metwally, M.-E. A., \& Zakey, S. E. (2018). Utilizing industrial waste-water as alkali activator in sandcement kiln dust bricks. Construction and Building Materials, 182, 284-289.

Al-Fakih, A., Mohammed, B. S., Liew, M. S., \& Nikbakht, E. (2019). Incorporation of waste materials in the manufacture of masonry bricks: An updated review. Journal of Building Engineering, 21, 37-54.

Amin, S. K., Sherbiny, S. A. El, El, A. A. M. A., Belal, A., \& Abadir, M. F. (2017). Fabrication of geopolymer bricks using ceramic dust waste. Construction and Building Materials, 157, 610-620. https://doi.org/10.1016/j.conbuildmat.2 017.09 .052

Babu, S. V. G., \& Krishnaiah, S. (2018). Manufacturing of eco-friendly brick: A critical review. 24-32.

Balaji, B., Bhattacharya, A., Fierro, G., Gao, J., \& Gluck, J. (2018). Brick : Metadata schema for portable smart building applications. Applied Energy, February, 1-20. https://doi.org/10.1016/j.apenergy.2018 .02 .091

Dang, J., Zhao, J., Hu, W., Du, Z., \& Gao, D. (2018). Properties of mortar with waste clay bricks as fine aggregate. Construction and Building Materials, 166, 898-907.

Dhandhukia, P., Goswami, D., Thakor, P., \& Thakker, J. N. (2013). Soil property apotheosis to corral the finest compressive strength of unbaked adobe bricks. Construction and Building Materials, 48, 948-953.

Hadi, N. A. R. A., \& Abdelhadi, M. (2018). Characterization and utilization of oil shale ash mixed with granitic and marble wastes to produce lightweight bricks. Oil Shale, 35(1), 56-69.

Joglekar, S. N., Kharkar, R. A., Mandavgane, S. A., \& Kulkarni, B. D. (2017). SC. Sustainable cities and society.

https://doi.org/10.1016/j.scs.2017.11.02 5

Kadir, A. A., \& Sarani, N. A. (2012). An overview of wastes recycling in fired clay bricks. International Journal of Integrated Engineering, 4(2), 53-69.

Kizinievi, O., Kizinievi, V., Pundiene, I., \& Molotokas, D. (2018). Eco-friendly fired clay brick manufactured with agricultural solid waste. ScienceDirect, $8,0-9$.

https://doi.org/10.1016/j.acme.2018.03. 003

Letelier, V., Ortega, J., Muñoz, P., Tarela, E., \& Moriconi, G. (2018). Influence of waste brick powder in the mechanical properties of recycled aggregate concrete. Sustainability, 10(4), 1037.

Minhaj, S., Kazmi, S., Junaid, M., Patnaikuni, I., Wu, Y., \& Fawad, U. (2018). Thermal performance enhancement of eco-friendly bricks incorporating agro-wastes. Energy \& Buildings, 158, 1117-1129. 
https://doi.org/10.1016/j.enbuild.2017. 10.056

Monteiro, S. N., \& Vieira, C. M. F. (2014). On the production of fired clay bricks from waste materials: A critical update. Construction and Building Materials, 68, 599-610.

Muntohar, A. S. (2011). Engineering characteristics of the compressedstabilized earth brick. Construction and Building Materials, 25(11), 42154220.

https://doi.org/10.1016/j.conbuildmat.2 011.04.061

Murmu, A. L., \& Patel, A. (2018). Towards sustainable bricks production: An overview. Construction and Building Materials, 165, 112-125. https://doi.org/10.1016/j.conbuildmat.2 018.01 .038

Phonphuak, N., Kanyakam, S., \& Chindaprasirt, P. (2016). Utilization of waste glass to enhance physicalmechanical properties of fired clay brick. Journal of Cleaner Production, 112, 3057-3062.

Poinot, T., Laracy, M. E., Aponte, C., Jennings, H. M., Ochsendorf, J. A., \& Olivetti, E. A. (2018). Beneficial use of boiler ash in alkali-activated bricks. Resources, Conservation \& Recycling, 128(August 2017), 1-10. https://doi.org/10.1016/j.resconrec.201 7.09.013

Rahman, A. (2014). Influence of Rice husk ash and fly ash on properties of red clay. January 2015. https://doi.org/10.3329/jsr.v6i3.15343

Rajkumar, P. R. K., Krishnan, K. D., Sudha, C., Ravichandran, P. T., \& Vigneshwaran, T. D. (2016). Study on use of industrial waste in preparation of green bricks. Indian Journal of Science and Technology, 9, 5.

Rani, M. Y., Bhagawan, D., Himabindu, V., Reddy, V. V., \& Saritha, P. (2016). Preparation and characterization of green bricks using pharmaceutical industrial wastes. Environmental
Science and Pollution Research, 23(10), 9323-9333.

Raut, S. P., Sedmake, R., Dhunde, S., Ralegaonkar, R. V, \& Mandavgane, S. A. (2012). Reuse of recycle paper mill waste in energy absorbing lightweight bricks. Construction and Building Materials, 27(1), 247-251.

Seco, A., Omer, J., Marcelino, S., Espuelas, S., \& Prieto, E. (2018). Sustainable unfired bricks manufacturing from construction and demolition wastes. Construction and Building Materials, 167 , 154-165. https://doi.org/10.1016/j.conbuildmat.2 018.02.026

Silva, G. H. M. J. S. De, \& Perera, B. V. A. (2018). E ff ect of waste rice husk ash (RHA) on structural, thermal and acoustic properties of fi red clay bricks. Journal of Building Engineering, 18(March), 252-259. https://doi.org/10.1016/j.jobe.2018.03.0 19

SNI 15-2094-2000, SII-0021-1978. National Standardization Agency of Indonesia.

Soultana, A., Valouma, A., Bartzas, G., \& Komnitsas, K. (2019). Properties of Inorganic Polymers Produced from Brick Waste and Metallurgical Slag. Minerals, 9(9), 551.

Taha, Y., Benzaazoua, M., Edahbi, M., Mansori, M., \& Hakkou, R. (2018). Leaching and geochemical behavior of fi red bricks containing coal wastes. Journal of Environmental Management, 209, 227-235. https://doi.org/10.1016/j.jenvman.2017. 12.060

Velasco, P. M., Ortíz, M. P. M., Giró, M. A. M., \& Velasco, L. M. (2014). Fired clay bricks manufactured by adding wastes as sustainable construction material - A review. 63, 97-107. https://doi.org/10.1016/j.conbuildmat.2 014.03.045

Zhang, L. (2013). Production of bricks from waste materials-A review. Construction and Building Materials, 47, 643-655. 
